\title{
GAMBARAN BRANDING ESGRIM HOUSE SEMARANG MELALUI MEDIA SOSIAL
}

\author{
Octaviana \\ (octavianaoctaviana792@yahoo.co.id) \\ (Mahasiswa S1 Program Studi Ilmu Komunikasi Universitas Semarang)
}

\begin{abstract}
This paper seeks to understand the extent to which social media provides the effect of doing branding Esgrim House Semarang. theoretical basis in this paper is the Narrative Paradigm of Walter Fisher stressed that man is a storyteller and that consideration will be of value, emotion and aesthetics into the basic beliefs of our behavior, or simply refers to the understanding as well as the reaction of everyone when receiving messages the disampaiakan. From these results, it was found that a storyteller admin is his, whereas kususnya twitter and social media instagram serve as tools in the communication process Esgrim House Semarang. So preformance this case, social media has a role to introduce products, information centers, as well as archiving online gallery measuring instrument success in branding Esgrim House Semarang.
\end{abstract}

Kata Kunci : Narrative Paradigm, Branding, Media Sosial

\section{Pendahuluan}

Esgrim House Semarang merupakan kedai ice cream yang menjangkau semua kalangan, terutama para kaum muda yang ingin menghabiskan waktu luangnya. Kedai ini didirikan oleh empat anak muda yang memiliki visi serta misi yang sama yakni ingin menjadi pengusaha muda dan sukses mulia di usia yang relatif muda, serta ingin membuat lapangan pekerjaan agar bisa bermanfaat bagi orang banyak. Mereka ini adalah Didith Haryo Wicaksono P, Dimas Yudha Prawira, Lanang Pradana, serta Kuncoro Adi Prasetyo. Esgrim House Semarang sendiri untuk pertama kalinya didirikan pada tanggal 5 Desember 2014, dengan cabang pertama yang berada di Jalan Singosari Timur Nomor H-4 Semarang. Dan pada bulan Oktober 2015, Esgrim House memiliki cabang kedua di Semarang yakni berada di Jalan Parang Baris Raya Nomor 32 Semarang. Sedangkan untuk kantornya berada di Jalan Cinde
Selatan I Nomor 78 Semarang. Berdasarkan menu yang ditawarkan, Esgrim House Semarang membagi menjadi empat menu, yakni ice cream, drink, food, serta take away menu. Misalnya saja pada menu ice cream, yakni terdapat cheese french toast, triple pancake, banana oreo, cheese durian, choco toast bread, french toast grim, james brown, grim cracker, choco durian, serta masih banyak lainnya. Harga yang ditawarkan pun, relatif murah, yakni dimulai dari harga Rp 8000,00 hingga Rp 14.000,00. yakni dimulai dari harga Rp 8000,00 hingga Rp 14.000,00.

Selain itu, untuk mempertahankan kesetiaan para pengunjung serta pelanggan nya, pihak Esgrim House memiliki cara lain untuk menjalankannya. Yakni melalui berbagai promo menarik yang dberikan di tempat, promo ini terdiri dari : buka puasa di Esgrim House Semarang yakni bagi yang berpuasa di hari Senin dan Kamis akan mendapatkan 1 menu gratis 
dengan syarat buka puasa di Esgrim House Semarang, Student Day yakni bagi pelajar yang menunjukkan kartu pelajar akan mendapatkan diskon

$10 \%$ yang berlangsung pada hari selasa pukul 12.00 hingga 17.00, Hijaber Day yang berlangsung pada hari Rabu dengan syarat kaum wanita yang berhijab mendapatkan pototngan harga sebesar $10 \%$ yang berlangsung di jam yang sama pula, yakni 12.00 hingga 17.00. Nota Total 50K atau $\mathrm{Rp}$ $50.000,00$ akan mendapatkan gratis menu Affogato/ Strawberry Jelly Soup. Diskon Ulang Tahun, yakni para pengunjung akan mendapatkan diskon sesuai dengan umur nya.

Dalam hal layanan, para karyawan begitu hangat kepada para customer, dengan antusias mereka sangat komunikatif serta ramah terhadap para pengunjung kedai ice cream yang satu ini. Tidak heran, dengan konsep yang sederhana, ditunjang dengan harga yang murah dan pelayanan yang baik, menjadikan para pelanggan yang datang untuk kembali lagi, sesekali menghabiskan waktu luang nya atau hanya sekdear nongkrong. Diluar menu yang ditawarkan serta dalam pelayanan, hal lain yang perlu digaris bawahi disini adalah pemanfaatan akun media sosial yang dimiliki oleh Esgrim House Semarang. Dimana akun ini berperan sebagai jembatan komunikasi ekternal antara pelanggan dengan pihak Esgrim House Semarang itu sendiri. Kehadiran media sosial twitter serta instagram seperti halnya menjadi senjata dari pihak Esgrim House untuk memberikan segala informasi yang berkaitan dengan Esgrim House Semarang.

Hal yang melatar belakangi Peneliti melakukan penelitian ini dikarenakan Peneliti tertarik untuk menggali lebih dalam akan kehadiran media sosial yang ada di Esgrim House
Semarang serta bagaimana perannya dalam menunjang proses komunikasi dengan para pelanggannya. Adapun tujuan dari penelitian ini adalah untuk mendeskripsikan peran media sosial dalam melakukan branding Esgrim House Semarang. Sehingga kedepannya penelitian ini memiliki manfaat untuk mengkaji teori Narrative Pradigm, selain itu hasil penelitian ini diharapkan dapat menjadi referensi bagi perusahaan atau jenis usaha lainnya dalam upaya memperbaikki komunikasi kepada pelanggannya melalui pemanfaatan teknologi khususnya media sosial untuk menjangkau calon pelanggan bahkan pelanggan lainnya secara lebih luas, serta menjaga hubungan baik antara

keduanya demi kemajuan perusahaan ataupun usaha yang dijalankan. perusahaan ataupun usaha yang dijalankan.

Narrative Paradigm (Paradigma Naratif) diperkenalkan oleh Walter Fisher. pada tahun 1984. Narrative Paradigm menurut (Griffin, 2006:341) narasi merupakan bentuk komunikasi yang berakar dalam ruang dan waktu. Ini mencakup setiap aspek kehidupan kita dan kehidupan orang lain dalam hal karakter, motif, dan tindakan. Istilah ini juga mengacu pada setiap tawaran verbal atau nonverbal bagi seseorang untuk percaya atau bertindak seperti apa yang diarahkan. Atau secara sederhana teori ini membahas tentang manusia adalah makhluk pencerita dan apabila pertimbangan akan nilai, emosi, dan estetika merupakan dasar keyakinan dan perilaku kita.

Integrated Marketing Communication merupakan suatu program awal yang perlu dilakukan oleh suatu Perusahaan dalam membina hubungan dengan pelanggannya sebelum melakukan program yang lainnya. Fokus dari IMC-nya pada aktivitas komunikasi perusahaan kepada 
konsumen yang dituju, dan kita mengetahui bahwa aktivitas dasar dari sebuah hubungan merupakan sebuah komunikasi. Dimana dalam hal ini hadirnya IMC menjadi sebuah strategi bisnis proses yang digunakan untuk mengembangkan, mengeksekusi, mengevaluasi, mengukur, suatu program komunikasi brand dalam jangka waktu tertentu kepada konsumen, pelanggan, karyawan, dan target lainnya baik itu untuk pemirsa internal maupun eksternal perusahaan.

Berbicara mengenai branding tidak terlepas dari kata dasar brand. Yang mana brand merupakan nama, simbol atau identitas dari suatu produk yang dikeluarkan oleh perusahaan yang untuk mengenalkannya kepada konsumen melalui proses yang disebut branding. Seperti halnya pada branding terhadap Esgrim House memiliki tujuan yang sama. Yakni untuk menyampaikan pesan dalam bentuk informasi dengan jelas, memastikan kredibilitas, mampu menghubungkan target pasar secara emosional, serta memastikan terciptanya kesetiaan pelanggan. Point yang terpenting disini ialah kesetiaan pelanggan, dalam hal ini adalah para pelanggan Esgrim House Semarang. Dikarenakan dengan pelanggan yang setia, merupakan bukti bahwa apa yang diharapkan oleh pelanggan sudah sesuai dan terpenuhi, sehingga hal ini pula yang menjadi acuan tersendiri bagi Esgrim House Semarang dalam mempertahankan kesetiaan pelanggan guna menunjang keberhasilan dalam bentuk pendapatan.

Media sosial merupakan seperangkat teknologi mudah digunakan yang memungkinkan serta mempertemukan manusia dari seluruh penjuru dunia dalam satu genggaman saja. Berbagai manfaat bisa diperoleh dari media sosial itu sendiri. Baik itu digunakan di dalam bidang pendidikan, pemerintahan, maupun di dalam sebuah pertumbuhan dan kemajuan sebuah perusahaan sebagai poros bisnis kehidupan. Sifatnya yang cepat, ringkas, jangkauan luas, padat dan sederhana menjadikan segala hal yang dibutuhkan menjadi lebih ptaktis. Seperti halnya instagram dan twitter, yang kedua nya merupakan media sosial yang menawarkan beragam fitur yang praktis dan mudah digunakan. sendiri. Baik itu digunakan di dalam bidang pendidikan, pemerintahan, maupun di dalam sebuah pertumbuhan dan kemajuan sebuah perusahaan sebagai poros bisnis kehidupan. Sifatnya yang cepat, ringkas, jangkauan luas, padat dan sederhana menjadikan segala hal yang dibutuhkan menjadi lebih ptaktis. Seperti halnya instagram dan twitter, yang kedua nya merupakan media sosial yang menawarkan beragam fitur yang praktis dan mudah digunakan. Instagram adalah sebuah aplikasi yang digunakan untuk membagi - bagikan foto dan video. Dan instagram sendiri juga masih bagian dari facebook yang memungkinkan teman dari facebook dapat menfollow akun instagram (Nisrina, 2015:137). Fitur Fitur yang ada di instagram : pengikut, mengunggah foto, kamera, efek foto, judul foto, arroba, label foto, perlombaan, publikasi kegiatan sosial, publikasi organisasi, geotagging, jejaring sosial, tanda suka, populer, peraturan instagram, serta penandaan foto dengan bendera.

Sedangkan Twitter berawal dari sebuah diskusi yang diselenggarakan oleh anggota dewan dari Podcasting perusahaan Odeo. Dalam pertemuan tersebut, Jack Dorsey memperkenalkan ide twitter. Dengan twitter setiap individu bisa menggunakan SMS layanan untuk berkomunikasi dengan kelompok kecil. Dari hasil pertemuan 
itu, dimulilah proyek twitter yang secara terbuka pada tanggal 15 Juli 2006. Berikut ini fitur - fitur yang terdapat pada twitter : kicauan (tweet), konten, format, topik hangat, aplikasi dan seluler, serta verifikasi akun.

\section{Pembahasan}

Penelitian ini menggunakan metode penelitian yang digunakan adalah wawancara mendalam (indepth interview) dengan menggunakan analisis deskriptif kualitatif. Penelitian ini dilakukan di Kota Semarang berdasarkan teknik purposive sampling dengan wawancara oleh narasumber dari pemilik Esgrim House Semarang, praktisi di bidang Marketing Communication, ahli di bidang periklanan, serta tiga informan dari pelanggan setia Esgrim House Semarang. Berdasarkan hasil observasi dan wawancara Peneliti kepada Owner dan ketiga informan tersebut.

Beberapa hal yang menjadi cakupan luas dari penelitian ini adalah bagaimana sebuah media sosial yakni instagram serta twitter bisa membawa nama Esgrim House Semarang bisa dikenal oleh masyarakat secara luas serta memberikan dampak yang sangat positif bagi ownernya. Diluar dari sisi internal yang meliputi cita rasa produk, harga yang ditawarkan, serta dari layanan di tempat yang diberikan yang mengarah ke pendapat positif dari masing-masing pelanggan. Hasil observasi serta wawancara kepada owner Esgrim House Semarang pada dasarnya sudah memberikan gambaran baru bagi kita mengenai sisi lain yang dapat diambil dari media sosial itu sendiri. Terlebih dalam hal peran viral selayaknya Multi Level Marketing dalam dunia online. bagi kita mengenai sisi lain yang dapat diambil dari media sosial itu sendiri. Terlebih dalam hal peran viral selayaknya Multi Level Marketing dalam dunia online.
Para follower dimanjakan dengan konten yang dibagikan baik berupa berbagai informasi dari akun tersebut, yang meliputi: sarana promosi produk baru, promo diskon harian yang diberikan, aneka kuis yang diberikan, serta mengenai informasi tambahan yang berkaitan dengan Esgrim House Semarang. Dari sini mereka menilai kehadiran media sosial tersebut sangatlahefektif dalam hal branding Esgrim House Semarang dimata masyarakat terutam di kalangan anak muda. Yakni sebagai sarana komunikasi secara eksternal antara para pelanggan dengan pihak Esgrim House Semarang.

Penggunaan media sosial sebagai media komunikasi eksternal Esgrim House Semarang ini tidak jauh kaitannya dengan Integrated Marketing Communication, yang merupakan suatu program awal yang digunakan untuk mengembangkan, mengeksekusi, mengevaluasi, mengukur, suatu program komunikasi brand dalam jangka waktu tertentu kepada karyawan, pelanggan serta target lainnya. Maka dari sinilah Integrated Marketing Communication dalam Esgrim House Semarang ini sangat penting, dikarenakan fokus IMC ini pada aktivitas komunikasi Esgrim House Semarang kepada para pelanggan yang dituju melalui berbagai konten yang dibagikan. Yakni melalui gambar dilengkapi dengan deskripsi yang diberikan, video, serta melalui berbagai tulisan dalam bentuk postingan di akun media sosial nya.

Terlepas dari berbagai konten yang dibagikan, hal yang membuat menarik disini dan berbeda dengan yang lainnya adalah bagaimana media sosial tersebut menjadi pusat perhatian dari follower nya. Keunikan inipun sama halnya yang dijelaskan oleh praktisi di bidang Marketing Communication, yakni Gita Aprinta E,B,S.Sos.Msi yang 
menyebutkan apabila harus ada strategi mendasar untuk menarik perhatian dari pengguna media sosial tersebut. Dan strategi tersebut meliputi : konten yang menarik, hastag yang unik dan menjangkau khalayak luas, serta timing yang sesuai. Berbicara mengenai ketiga strategi mendasar diatas inilah yang menjadikan kerangka penelitian ini erat kaitannya dengan salah satu teori komunikasi yakni Narrative Paradigm atau paradigma naratif.

Hal yang sama juga terjadi di dalam penelitian ini, narasi yang dimaksudkan disini adalah tentang beberapa konten yang dibagikan oleh Esgrim House Semarang. Yang berupa caption atau yang menarik, unik, serta bermakna positif inilah yang menjadi nilai tambahan media sosial dari Esgrim House Semarang. Yang memiliki andil besar dalam hal ini adalah admin dari kedua media sosial tersebut dalam memberikan kesan menarik dalam setiap postingan yang dibagikan sesuai dengan standar yang telah ditentukan oleh ownedengan standar yang telah ditentukan oleh owner nya. Admin memiliki peluang luas dalam menyebarkan setiap kreatifitasnya melalui olahan kata kata yang dijabarkan, bagaiamana dia mencari follower, serta bagaimana pula admin berperan dalam maintenance para follower setianya dalam segala bentuk feedback.

Berdasarkan asumsi yang dijabarkan diatas tersebut, relevansi Paradigma Naratif dan penggunaan media sosial dalam branding Esgrim House Semarang sangat tepat, dimana dalam hal ini media sosial baik twitter maupun instagram merupakan sebuah tools yang membantu manusia yang dijalankan oleh admin dari media sosial tersebut sebagai makhluk pencerita. Cerita yang digambarkan disini adalah segala sesuatu yang dibagikan baik itu informasi mengenai kegiatan dari kedai, postingan menu, bentuk promosi yang berupa video atau gambar. Akan tetapi yang segala sesuatu yang dibagikan tersebut akan tidak efektif apabila tidak mempertimbangkan sasaran utama yang dimaksudkan. Jadi, yang perlu digaris bawahi disini adalah kepada siapa sang pencerita tersebut membagikan informasi nya. Jika sasarannya tepat maka akan diiringi dengan feedback dari pengguna media sosial lainnya dalam bentuk tanya jawab, maupun pengguna media sosial tersebut justru membantu dalam mempromosikan Esgrim House Semarang dalam bentuk postingan ulang maupun melalui fasilitas lain yang ada dalam fitur instagram maupun twitter.

Berawal dari sini, timbulah terbentuklah pola pikir dari follower maupun pengguna media sosial melalui interaksi dengan para pengguna lainnya mengenai gambaran seperti apakah Esgrim House Semarang tersebut, dan inilah yang dinamakan proses branding melalui pemanfaatan media sosial baik twitter maupun instagram dalam upaya memperkenalkan Esgrim House Semarang di khalayak luas. Seperti alnya yang diungkapkan oleh Budiman Hakim yang merupakan ahli di bidang periklanan yang menyatakan kelebihan dari media sosial ini. Budiman Hakim (wawancara Selasa, 12 Januari 2016 pukul 07.00 WIB) media sosial memungkinkan kita untuk saling berinteraksi. Berbeda dengan media tradisional yang hanya berkomunikasi satu arah. Inilah sebabnya peran media sosial mendadak sangat penting dan mendominasi. Hal ini dikarenakan, kita bisa jualan tanpa memiliki toko, kita bisa membuat lembaga pendidikan tanpa harus membangun gedung sekolah, kita bisa beriklan sepuasnya tanpa mengeluarkan biaya dibandingkan 
dengan beriklan di radio maupun televisi yang harus mengeluarkan biaya.

\section{Kesimpulan}

Melalui penelitian ini dapat disimpulkan bahwa media sosial khusunya twitter dan instagram memiliki peran yang sangat efektif, yakni sebagai tools guna menunjang proses komunikasi dalam hal ini adalah branding di Esgrim House Semarang. Tanpa harus keluar biaya, jangkauannya yang mudah didapat, serta mudah dilacak memungkinkan untuk pihak Esgrim House menjadikan nya sebagai wadah untuk mengenalkan produk (promosi), pusat informasi, pegarsipan galeri online, serta sebagai alat ukur keberhasilan kedai ice cream ini. Melalui konten yang dibagikan, ditunjang dengan penempatan timing yang sesuai serta interaksi yang baik antara Esgrim House Semarang dengan para pengguna media sosial yang baik inilah yang menjadikannya digandrungi, sehingga timbulah branding (pencitraan) tersendiri dari para pengguna media sosial yang sudah menjadi pelanggan setia maupun calon pelanggannya dikemudian hari nanti.

\section{Daftar Pustaka}

Griffin E.M. (2006). A First Look at Communication Theory 6th Edition. London : McGraw Hill Nisrina. 2015. Bisnis Online Manfaat Media Sosial dalam Meraup Uang. Yogyakarta : Kobis.

http://www.kemendag.go.id/files/pdf/20 15/01/15/buku media-sosialkementerian perdagangan-id0 1421300830.pdf,diakses pada Kamis, 15 Oktober 2015 pukul 11.00

http://library.binus.ac.id/eColls/eThesis doc/Bab2/Bab\%202_09219.pdf, diakses pada Kamis, 15 Oktober 2015 pukul 12.00. 